\title{
Drug Dosage Adjustment of Chronic Kidney disease Patients at Nephrology Ward in Tertiary Care Hospital of Nepal
}

\author{
Sonu Pakhrin ${ }^{1}$ *Sumitra Shrestha ${ }^{1}$, Renu Karki², Nirmal Raj Marasine ${ }^{2}$, Rajendra Lama ${ }^{3}$, Mandip Pokharel ${ }^{4}$
}

\section{Author Info:}

${ }^{1}$ Divine Healthcare Pvt. Ltd. Bharatpur-16, Chitwan, Nepal

${ }^{2}$ School of Health and Allied Sciences, Pokhara University, Dhungapatan, Pokhara, Nepal

${ }^{3}$ Pokhara academy of Health sciences, Ramghat, Pokhara, Nepal

${ }^{4}$ Program Manager, Vennue Foundation, Nepal

*Corresponding Author: Ms. Sumitra Shrestha sumitra.shrestha024@gmail.com

\begin{abstract}
Background: Drug dosage adjustment is essential for chronic kidney disease patients (CKD) patients. If it is not done properly, this will lead to an increase in toxicity and a decrease in the effectiveness of therapy. The objective of the present study was to assess whether appropriate dosage adjustments were made in hospitalized CKD patients.

Methods: A descriptive cross-sectional study was carried out among 80 CKD patients with stage II to $\mathrm{V}$ admitted in the nephrology ward of Chitwan Medical College Teaching Hospital, Nepal between 1st August to 30th November 2018. All patients with renal clearance $\leq 90 \mathrm{ml} / \mathrm{min} / 1.73$ $\mathrm{m} 2$ were included for the analysis. Data concerning patient's clinical, medications and dosages, laboratory findings were extracted from the medical record section.
\end{abstract}

Results: Total of 81 numbers of prescribed drugs was found in eighty hospitalized CKD patients. Twenty-seven were found requiring dose adjustment. Dose adjustment according to renal function was judged as necessary in 27 dose adjustment required drugs. Among these, 11 (40.7\% of 27) drugs were considered appropriate in dosing, whereas 16 (59.3\%) were found to be inappropriate. A total of 13 (81.3\%) number of drugs were inappropriately adjusted in stage $\mathrm{V}$ patients.

Conclusion: Dosing errors were the most frequently observed challenge in the patient hospitalized with CKD. This study also intensified the need for strong monitoring of drug therapy which will bear in achieving the better therapeutic outcomes that improve the quality of life and decrease the various problems associated with dosing error.

Keywords: appropriateness, chronic kidney disease, dose adjustment, drug dosage adjustment, Nepal, nephrology

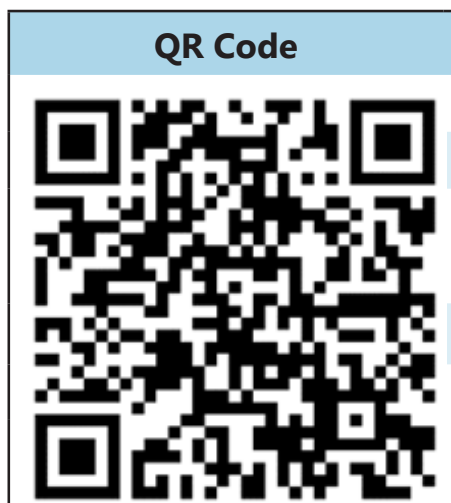

(A) View PDF

\section{Article Info}

Received: 1 March 2020; Accepted: 16 April 2020; Published Online: 17 Aprol 2020

How to cite this article in Vancouver Style?

Pakhrin S, Shrestha S, Karki R, Marasine NR, Lama R, Pokharel M. Drug Dosage Adjustment of Chronic Kidney disease Patients at Nephrology Ward in Tertiary Care Hospital of Nepal. Europasian J Med Sci.2020;2(1):41-50. https://doi.org/10.46405/ejms.v2i1.39

\section{Disclaimer}

Conflict of Interest: None Declared;

Source of Support: Nil

Copyright: ( $) 2020$ by author(s). This is an open access article distributed under the terms of the Creative Commons Attribution International License 4.0@_. (http://creativecommons.org/ licenses/by/4.0/) which permits unrestricted use, distribution, and reproduction in any medium, provided the original work is properly cited.

\section{Publisher's Note}

The Europasian Journal of Medical Sciences (EJMS) is an official Journal of Nirvana Psychosocial Care Center \& Research Institute (www. nirvanapscc.com) and published by it. The Journal as well as publisher remain neutral with regards to any jurisdictional claims in any published articles, its contents and the institutional affiliations of the authors.
} 


\section{INTRODUCTION}

Chronic kidney disease (CKD) is one of the most widely spreading health issues which showed about $8 \%$ to $16 \%$ of prevalence. ${ }^{1}$ Globally, hypertension and diabetes are the most leading cause of the renal problem. ${ }^{2}$ CKD is simply defined as kidney damage or Glomerular filtration rate (GFR) $<60$ $\mathrm{mL} / \mathrm{min} / 1.73 \mathrm{~m}^{2}$ for $\geq 3$ months which means abnormalities in pathological condition or markers of deterioration, involving blood abnormalities or urine tests or imaging studies ${ }^{3}$. The best way to measure kidney function is by measuring the GFR rate. ${ }^{4}$ The age, gender, and body size are the factors that alter the normal value of GFR, which value in a healthy adult is about 120 to $130 \mathrm{~mL} / \mathrm{min} / 1.73 \mathrm{~m}^{2}{ }^{2}{ }^{5}$

The alteration of renal excretion leads to the accumulation of drug metabolites in the case of patients with renal failure. ${ }^{6}$ Besides, the pharmacokinetic parameters like distribution and elimination were affected by significantly decreasing the plasma protein binding of drugs. Finally, these changes will happen due to altering in metabolizing enzymes and drug transporters in CKD patients. ${ }^{6}$ The proper monitoring of drug therapy is important for CKD patients to prevent drug dosage related problems like accumulation and toxicity, drug elimination is directly linked with the GFR rate so that it is logical to use eGFR or eCrCl for monitoring dosages in that case. ${ }^{7}$ The main aim of drug individualization is to optimize the therapeutic outcome and to reduce the drugrelated toxicity in CKD patients, there are two important methods for achieving this is either to lengthen the dosing interval or by reducing the dose. Firstly the loading dose needs not to be adjusted. Sometimes both the method needs to the adjusted. ${ }^{8}$ The proper dosage monitoring can help to reduce the morbidity rate and save the cost which also prevents the drug dosage related toxicity. ${ }^{9}$ In the case of patients with CKD if the dosage is not appropriate given which leads to an increase in toxicity and ineffective therapy. ${ }^{10}$ The elderly population is at a high risk of developing multiple advance diseases and associated adverse events, which may due to age-related decline in kidney function and the use of polypharmacy to treat their comorbid conditions. ${ }^{11-13}$

The limited number of studies 14,15 that evaluate drug dosage adjustment in CKD patients were conducted in Nepal. Therefore, this study was initiated to assess drug dosage adjustment among hospitalized patients with renal impairment at Chitwan Medical College Teaching Hospital (CMCTH), Chitwan, Nepal.

\section{MATERIALS AND METHODS}

Study design: The study design was a descriptive cross-sectional study.

Study area: The study was conducted in the nephrology ward of Chitwan Medical College Teaching Hospital (CMCTH), located in Bharatpur Chitwan, Nepal which is affiliated to Tribhuvan University and it is the first ISO certified Medical College, which has a 750-bed hospital.

Study Population, inclusion and exclusion criteria: The study population was all CKD patients admitted to the nephrology department of CMCTH. Patients older or equal to eighteen years of age, patients hospitalized for at least one day were included in the study. Patients undergoing kidney transplantation, patients who were critical in condition and unable to respond, mentally retarded and psychiatric patients and pregnant women of any trimester were excluded from the study.

Sample size determination: Census sampling was taken during the data collection period.

Duration of study: The data collection period was for 3 months from 17th August 2018 to 16th November 2018.

Data collection procedures: Data were collected using a structured questionnaire and patient medication profile form. The purpose of the structured questionnaire was to document a patient-related variable that includes, sociodemographic details of the patients (age, gender, marital status, religion, ethnic group, family type, education, source of income, average investment, insurance policy, etc. Patients medication profile form was designed to document subjective observation (chief complaints, medical history, family history, social history), objective observation (physical examination, vital sign, known allergies), lab investigation, hematology, urine Analysis, presenting complaints, stage of CKD, list of comorbidities, drug regimen (generic name of medications, number of medication used, dose, frequency, route, duration).

GFR was estimated based on creatinine clearance from serum creatinine $(\mathrm{SCr})$ using the Cockcroft 
Gault equation. ${ }^{16}$ All of the information was tabulated for analysis. Appropriateness was determined by comparing practice with the guideline "The Renal Drug Handbook". ${ }^{17}$

Ethical Considerations: The ethics approval was obtained from the Institutional Review Committee (IRC) of Pokhara University (Reference number IRC 21-075-76). Permission to conduct the study at the hospital was also obtained from the Department of Nephrology, Chitwan Medical College Teaching Hospital, Chitwan, Nepal. Before the data collection, formal permission was obtained from each participant and the respondents were informed about the purpose and objectives of the study. Privacy and confidentiality were maintained by not disclosing the name of the participants and ensuring them, that collected information was used only for the research purpose.

Data analysis: Data were entered and analyzed using Statistical Package for Social Science (SPSS) version 20. The data were summarized and described using tables and graphs. Descriptive statistics were used to describe demographic and disease characteristics of the patients. Percentages and frequencies were used for categorical variables, and means and standard deviations were calculated for continuous variables. Inferential statistics were used to evaluate the association of socio-demographic status with stages of CKD.

\section{RESULTS}

The socio-demographic and clinical characteristics of the patients. Eighty patients identified as having moderate to severe renal impairment, 32 (40\%) were male and 48 (60\%) were female. The patients had an average age of 58.90 years. Regarding educational status, the majority of patients (57.5\%) were illiterate and only $36.3 \%$ had gain School Level/SLC level education. The majority were in normal Body Mass Index (BMI) of $63.80 \%$. More than half $(61.3 \%)$ respondents had spent their 1-5 days of hospital staying period (table 1). The presenting complaints (complications) of CKD patients are shown in Table 2. Majority of patients $(n=19) \quad(21.25 \%)$ had hyperuricemia followed by UTI $(n=13)(16.25 \%)$, edema $(n=12) \quad(15 \%)$, hyponatremia $(n=11)$ (13.75\%). (table 2$)$

Figure 1 shows the appropriateness of prescribed drugs for CKD patients. Out of 81 number of prescribed drugs, 27 (33.33\%) required for the dose adjustment. Among them, 11 (40.74\%) were
Table 1: Socio-demographic and clinical characteristics of the patients

\begin{tabular}{|c|c|c|}
\hline Variable & Frequency & Percentage \\
\hline \multicolumn{3}{|l|}{ Age } \\
\hline $18-28$ & 4 & 5.0 \\
\hline $29-38$ & 5 & 6.3 \\
\hline $39-48$ & 18 & 22.5 \\
\hline $49-58$ & 14 & 17.5 \\
\hline$>59$ & 39 & 48.8 \\
\hline \multicolumn{3}{|l|}{ Gender } \\
\hline Male & 32 & 40.0 \\
\hline Female & 48 & 60.0 \\
\hline \multicolumn{3}{|l|}{ Education } \\
\hline Illiterate & 46 & 57.5 \\
\hline School Level/SLC & 29 & 36.3 \\
\hline Intermediate & 4 & 5.0 \\
\hline Bachelor or above & 1 & 1.3 \\
\hline \multicolumn{3}{|l|}{$\mathrm{BMI}$} \\
\hline Underweight & 24 & 30.0 \\
\hline Normal weight & 51 & 63.8 \\
\hline Overweight & 5 & 6.3 \\
\hline \multicolumn{3}{|c|}{ Length of hospital stay } \\
\hline $1-5$ & 49 & 61.3 \\
\hline $6-10$ & 25 & 31.3 \\
\hline $11-15$ & 6 & 7.5 \\
\hline \multicolumn{3}{|c|}{ Patients with a stage of renal Impairment } \\
\hline Stage II & 3 & 3.8 \\
\hline Stage III & 4 & 5 \\
\hline Stage IV & 20 & 25 \\
\hline Stage V & 53 & 66.3 \\
\hline
\end{tabular}

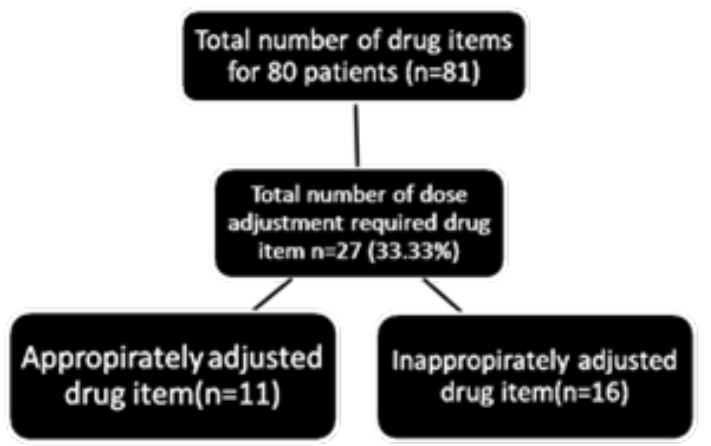

Figure 1: Appropriateness of prescribed drug for CKD patients 
Table 2: Presenting complaints of CKD patients

\begin{tabular}{|l|l|l|}
\hline Complication & Frequency & Percent \\
\hline Hyperuricemia & 19 & 23.75 \\
\hline $\begin{array}{l}\text { Urinary Tract } \\
\text { Infection }\end{array}$ & 13 & 16.25 \\
\hline Edema & 12 & 15 \\
\hline Hyponatremia & 11 & 13.75 \\
\hline Seizure & 6 & 7.5 \\
\hline $\begin{array}{l}\text { Lower Respiratory } \\
\text { Tract Infection }\end{array}$ & 8 & 10 \\
\hline $\begin{array}{l}\text { Chronic Obstructive } \\
\text { Pulmonary Disease }\end{array}$ & 4 & 5 \\
\hline $\begin{array}{l}\text { Upper Respiratory } \\
\text { Tract Infection }\end{array}$ & 3 & 3.75 \\
\hline Hyperkalemia & 2 & 2.5 \\
\hline Hypoglycemia & 2 & 2.5 \\
\hline Total & 80 & 100 \\
\hline
\end{tabular}

Table 3: Commonly prescribed drug

\begin{tabular}{|l|l|l|}
\hline Therapeutic Category & Frequeny & Percentage \\
\hline Antihypertensive & 139 & 22.24 \\
\hline Haematinics Pump & 78 & 12.48 \\
\hline $\begin{array}{l}\text { Proton } \\
\text { Inhibitor }\end{array}$ & 69 & 11.04 \\
\hline Antimicrobials & 47 & 7.52 \\
\hline Antacids & 37 & 5.92 \\
\hline Phosphate Binder & $36 \mathrm{R}$ & 5.76 \\
\hline Antiemetic & 35 & 5.6 \\
\hline Anticoagulant & 33 & 5.28 \\
\hline Hypoglycemic Drugs & 31 & 4.96 \\
\hline Antigout & 30 & 4.8 \\
\hline Nonsteroidal Anti- & 20 & 3.2 \\
\hline Inflammatory Drug & 14 & 2.24 \\
\hline Antihyperlipidemic & 14 & 2.24 \\
\hline Corticosteroids & 14 & 1.92 \\
\hline Anticonvulsant & 12 & 1.44 \\
\hline Antihistamine & 9 & 1.12 \\
\hline Antispasmodic & 7 & 1.12 \\
\hline Anti-thyroid & 7 & 0.8 \\
\hline Analgesic & 5 & 0.32 \\
\hline Anthelmintics & 2 & 100 \\
\hline Total & 625 & \\
\hline & & \\
\hline
\end{tabular}

appropriately adjusted drug and the remaining 16 (59.25\%) items were inappropriately adjusted.

Table 3 shows the commonly prescribed medications for CKD patients. This table showed that antihypertensive was the most commonly used medication $(n=139)(22.24 \%)$ which was followed by drugs for anemia and dietary supplements $(\mathrm{n}=78)(12.48 \%)$ and proton pump inhibitor $(n=69)(11.04 \%)$.

Regarding stage-wise appropriateness of drugs, a higher number of drugs 13 (81.3\%) were inappropriately adjusted in stage $\mathrm{V}$ while among appropriately adjusted 11 drugs, 6 (54.54\%) of drugs were found appropriately adjusted for stage IV (Figure. 2).

Figure 2: Appropriateness of drugs by stage of CKD

The result showed that the majority $(n=7)(64 \%)$ of drug items were adjusted appropriately in age

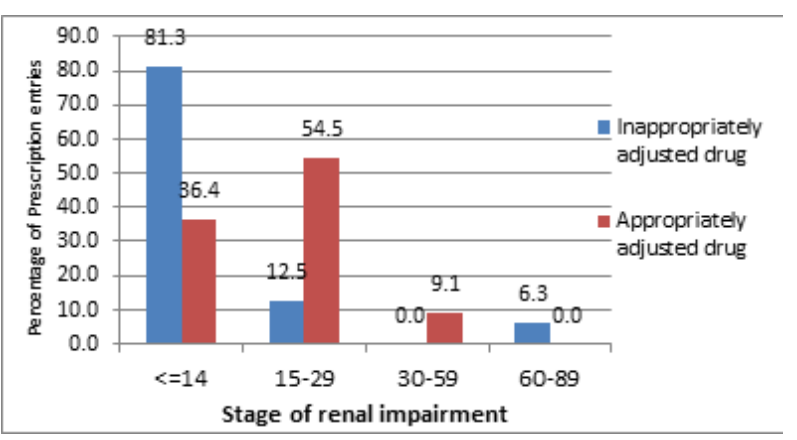

$>59$ and $(n=8) 50 \%$ of drug items were adjusted inappropriately in the same age group (Figure 3 ).

Table 4 shows the frequency of inappropriately adjusted drugs. Majority $(n=18)(41.9 \%)$ of drug inappropriately adjusted were from an antibiotic group (ciprofloxacin, levofloxacin, meropenem, nitrofurantoin). Among these antibiotics, nitrofurantoin $(n=6)(14 \%)$ was the most commonly prescribed inappropriate drug.

Figure 3: Appropriateness of drug across various age group

Table 5 shows the frequency of appropriately adjusted drugs. The majority $(n=11)(24.4 \%)$ of drugs piperacillin+tazobactum were appropriately adjusted while nebivolol only $(n=1)(2.2 \%)$ were adjusted appropriately which was very less than other remaining drugs. 
Table 6 shows an association between stages of chronic kidney disease and socio-demographic characteristics. In this study, age was found to be significantly associated with the stages of CKD but other socio-demographic variables were not found associated with stages of CKD.

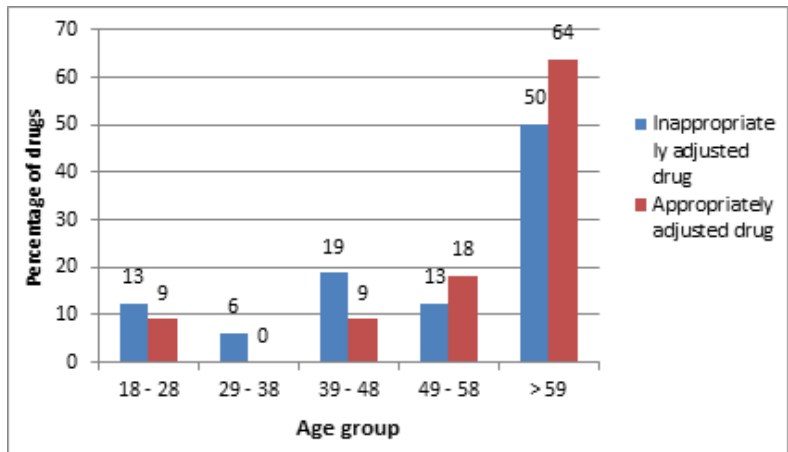

Table 4: Frequency of inappropriately adjusted drugs

\begin{tabular}{|l|l|l|}
\hline $\begin{array}{l}\text { Inappropriately adjusted } \\
\text { drugs }\end{array}$ & $\mathrm{N}$ & $\%$ \\
\hline $\begin{array}{l}\text { Acetaminophen+Tramadol } \\
\text { Ciprofloxacin }\end{array}$ & 2 & 4.7 \\
\hline Fenofibrate & 1 & 7.0 \\
\hline Fexofenadine Hydrochloride & 5 & 11.6 \\
\hline $\begin{array}{l}\text { Hydrochlorthiazide + Losartan } \\
\text { potassium }\end{array}$ & 3 & 7.0 \\
\hline Ketorolac tromethamine & 1 & 2.3 \\
\hline Levofloxacin & 5 & 11.6 \\
\hline Losartan potassium & 2 & 4.7 \\
\hline Meropenem & 4 & 9.3 \\
\hline Metformine Hydrochloride & 1 & 2.3 \\
\hline Metoprolol tartrate & 4 & 9.3 \\
\hline Nitrofurantoin & 6 & 14.0 \\
\hline Pregabalin & 1 & 2.3 \\
\hline Rosuvastatin & 1 & 2.3 \\
\hline Sitagliptin & 3 & 7.0 \\
\hline Spironolactone & 1 & 2.3 \\
\hline
\end{tabular}

Table 7 shows an association between stages of chronic kidney disease and the number of prescribed drugs. In this study, the number of prescribed drugs was found to be significantly associated with the various stages of CKD.
Table 8 shows an association between a number of

Table 5: Frequency of appropriately adjusted drugs

\begin{tabular}{|l|l|l|}
\hline Appropriately adjusted drugs & $\mathrm{N}$ & $\%$ \\
\hline Acetaminophen & 6 & 13.3 \\
\hline Clonazepam & 5 & 11.1 \\
\hline Insulin & 8 & 17.8 \\
\hline Levocetirizine & 4 & 8.9 \\
\hline Nebivolol & 1 & 2.2 \\
\hline Piperacillin+Tazobactum & 11 & 24.4 \\
\hline Potassium chloride & 3 & 6.7 \\
\hline Tramadol & 4 & 8.9 \\
\hline Phenobarbitone & 2 & 4.4 \\
\hline Sodium valproate & 1 & 2.2 \\
\hline
\end{tabular}

prescribed drugs and comorbidity of CKD. In this study, the number of prescribed drugs was found to be significantly associated with the various comorbidities of CKD.

\section{DISCUSSION}

The present study has shown that, of the total study population, $66.3 \%$ had stage $\mathrm{V}, 25 \%$ had stage IV, $5 \%$ had stage III and $3.8 \%$ had stage II CKD. This result is consistent with other studies conducted in India in which $76 \%$ had stage V, 18\% had stage IV and $6 \%$ had stage III CKD. ${ }^{18}$ The patient with stage $\mathrm{V}, \mathrm{CKD}$ is higher in this study which may be due to the absence of symptoms in stages I and II, while minimal and common symptoms are observed in stages III, IV and V respectively. This finding contradicts the study done by Kuznik A et al., 2013, which found a higher prevalence (49.1\%) in stage III and very low (3.7\%) in stage IV CKD. ${ }^{19}$

The present study has shown that the mean age of the CKD patients was 58.90 while the age group of $>59$ years comprises the highest percent (48.8\%). This showed the prevalence of CKD is seen in older age groups however the study from Nepal, National Kidney Center, Banasthali, Kathmandu, the mean age of the CKD patients was 47 years while the age group between 41-60 years comprises the highest percent. $^{20}$

In this study, $58.8 \%$ of patients were normal in $\mathrm{BMI}, 30 \%$ were underweight and only $6.3 \%$ were overweight. This finding contradicts the study 
Table 6: Association between stages of chronic kidney disease and socio-demographic characteristics

\begin{tabular}{|c|c|c|c|c|c|c|}
\hline \multirow{2}{*}{$\begin{array}{l}\text { Characteristics } \\
\text { Age }\end{array}$} & \multicolumn{4}{|c|}{ Stages of CKD } & \multirow{2}{*}{$\begin{array}{l}\text { Chi- } \\
\text { square }\end{array}$} & \multirow[t]{2}{*}{$\mathrm{p}$-value } \\
\hline & II & III & IV & $\mathbf{V}$ & & \\
\hline $18-28$ & $4(100)$ & 0 & 0 & 0 & \multirow{5}{*}{26.6} & \multirow{5}{*}{$0.009^{*}$} \\
\hline $29-38$ & $4(80)$ & 0 & 0 & $1(20)$ & & \\
\hline $39-48$ & $12(66.7)$ & $3(16.7)$ & $1(5.6)$ & $2(11.1)$ & & \\
\hline $49-58$ & $14(0)$ & & & 0 & & \\
\hline $\begin{array}{l}>59 \\
\text { Gender }\end{array}$ & $19(48.7)$ & 17(43.6) & $3(7.7)$ & 0 & & \\
\hline \multicolumn{7}{|l|}{ Gender } \\
\hline Female & $32(66.7)$ & $11(22.9)$ & $3(6.3)$ & $2(4.2)$ & 6.2 & 0.88 \\
\hline \multicolumn{7}{|l|}{ BMI } \\
\hline Under weight & $18(75)$ & $4(16.7)$ & $1(4.2)$ & $1(4.2)$ & \multirow{3}{*}{2.2} & \multirow{3}{*}{0.9} \\
\hline Normal weight & $32(62.7)$ & $14(27.5)$ & $3(5.9)$ & $2(3.9)$ & & \\
\hline Over weight & $3(60)$ & $2(40)$ & 0 & 0 & & \\
\hline \multicolumn{7}{|l|}{ Source of income } \\
\hline Agriculture/Farming & $21(70)$ & $7(23.3)$ & $2(6.7)$ & 0 & \multirow{6}{*}{9.67} & \multirow{6}{*}{0.84} \\
\hline Family Business & $15(68.2)$ & $5(22.7)$ & $1(4.5)$ & $1(4.5)$ & & \\
\hline Remittance & $8(66.7)$ & $3(25)$ & 0 & $1(8.3)$ & & \\
\hline Private/Government Job & $4(66.7)$ & $1(16.7)$ & 0 & 1(16.7) & & \\
\hline Labor/Daily wages & $2(50)$ & $2(50)$ & 0 & 0 & & \\
\hline Pension & $3(50)$ & $2(33.3)$ & $1(16.7)$ & 0 & & \\
\hline \multicolumn{7}{|l|}{ Marital status } \\
\hline Married & $45(71.4)$ & 13(20.6) & $2(3.2)$ & $3(4.8)$ & \multirow{4}{*}{11.26} & \multirow{4}{*}{0.25} \\
\hline Unmarried & $1(100)$ & 0 & 0 & 0 & & \\
\hline Divorced & $2(100)$ & 0 & 0 & 0 & & \\
\hline Widow/Widower & $5(35.7)$ & $7(50)$ & $2(14.3)$ & 0 & & \\
\hline \multicolumn{7}{|l|}{ Religion } \\
\hline Hinduism & $37(63.8)$ & $15(25.9)$ & $4(6.9)$ & $2(3.4)$ & & \\
\hline Mushilm & $2(50)$ & $1(25)$ & 0 & $1(25)$ & & \\
\hline Buddhism & $11(78.6)$ & $3(21.4)$ & 0 & 0 & 1.69 & 0.56 \\
\hline Christianity & $3(75)$ & $1(25)$ & 0 & 0 & & \\
\hline Type of family & & & & & & \\
\hline Nuclear & 14(82.4) & $3(17.6)$ & 0 & 0 & & \\
\hline Joint & $31(63.3)$ & $13(26.5)$ & $4(8.2)$ & $1(2)$ & 9.08 & 0.16 \\
\hline Extended & $8(57.1)$ & $4(28.6)$ & 0 & $2(14.3)$ & & \\
\hline Monthly Income & & & & & & \\
\hline Rs. 5000 - Rs. 10,000 & $2(5.9)$ & $1(2.9)$ & $7(2.6)$ & $24(70.6)$ & & 0.838 \\
\hline Rs. 15,000 -Rs. 30,000 & $1(2.8)$ & $2(5.6)$ & $11(30.6)$ & $22(61.1)$ & 2.759 & \\
\hline Rs. $35,000-$ Rs. 60,000 & 0 & $1(10)$ & $2(20)$ & $7(70)$ & & \\
\hline Education status & & & & & & \\
\hline Illiterate & $30(65.2)$ & $14(30.4)$ & $2(4.3)$ & 0 & & \\
\hline School Level/SLC & $21(72.4)$ & $3(10.3)$ & $2(6.9)$ & $3(10.3)$ & 13.05 & 0.16 \\
\hline Intermediate & $2(50)$ & $2(50)$ & 0 & 0 & & \\
\hline Numbers of cigarette smok & per day & & & & & \\
\hline 1-5 cigarette/day & $9(69.2)$ & $3(23.1)$ & $1(7.7)$ & 0 & & \\
\hline 6-15 cigarette/day & $14(51.9)$ & $12(44.4)$ & 0 & 1(3.7) & 11.94 & 0.063 \\
\hline Whole packet & $7(77.8)$ & 0 & $2(22.2)$ & 0 & & \\
\hline Ever consumed alcohol pro & & & & & & \\
\hline Yes & $24(75)$ & $6(18.8)$ & 1(3.1) & 1(3.1) & & \\
\hline No & $29(60.4)$ & 14(29.2) & $3(6.3)$ & $2(4.2)$ & 1.88 & 0.59 \\
\hline If consumed alcohol, freque & $y$ of drinki & alcohol & & & & \\
\hline Low (<1 glass/week) & $37(92.5)$ & $3(7.5)$ & 0 & 0 & & \\
\hline Moderate (1-3 glass/week) & $5(62.5)$ & $1(12.5)$ & $1(12.5)$ & $1(12.5)$ & 19.21 & 0.084 \\
\hline High (> 3 glass/week) & $6(66.7)$ & $3(33.3)$ & 0 & 0 & & \\
\hline Heavy Drinker & $3(100)$ & 0 & 0 & 0 & & \\
\hline
\end{tabular}


Table 7: Association between stages of chronic kidney disease and the number of prescribed drug

\begin{tabular}{|c|c|c|c|c|c|c|}
\hline \multirow[b]{2}{*}{ Number of drugs } & \multicolumn{4}{|c|}{ Stages } & \multirow{2}{*}{ Chi-square } & \multirow{2}{*}{ p-value } \\
\hline & II & III & IV & $\mathbf{v}$ & & \\
\hline 4 & $1(100)$ & 0 & 0 & 0 & \multirow{10}{*}{45.018} & \multirow{10}{*}{$0.016^{*}$} \\
\hline 5 & 0 & $1(16.7)$ & $3(50.0)$ & $2(33.3)$ & & \\
\hline 6 & $1(7.1)$ & $2(14.3)$ & 0 & $11(78.6)$ & & \\
\hline 7 & 0 & $1(5.9)$ & $7(41.2)$ & $9(52.9)$ & & \\
\hline 8 & $1(6.2)$ & 0 & $4(25)$ & $11(68.8)$ & & \\
\hline 9 & 0 & 0 & $4(28)$ & $10(72)$ & & \\
\hline 10 & 0 & 0 & 0 & $3(100)$ & & \\
\hline 11 & 0 & 0 & $1(20)$ & $4(80)$ & & \\
\hline 12 & 0 & 0 & $1(33)$ & $2(67)$ & & \\
\hline 13 & 0 & 0 & 0 & $1(100)$ & & \\
\hline
\end{tabular}

Table 8: Association between the number of prescribed drug and comorbidity of CKD

\begin{tabular}{|c|c|c|c|c|c|}
\hline \multirow{2}{*}{$\begin{array}{c}\text { Number of } \\
\text { drugs }\end{array}$} & \multicolumn{3}{|c}{ Comorbidity } & Chi-square & p-value \\
\cline { 1 - 4 } & Single & Double & Multiple & \\
\hline 4 & $1(100)$ & 0 & 0 & $0.000^{\star}$ \\
\hline 5 & $5(83.3)$ & 0 & $1(16.7)$ & \\
\hline 7 & $13(92.9)$ & $1(7.1)$ & 0 & \\
\hline 8 & $12(70.6)$ & $5(29.5)$ & 0 & \\
\hline 9 & $12(75.0)$ & $4(25.0)$ & 0 & \\
\hline 10 & $4(28.6)$ & $10(71.4)$ & 0 & \\
\hline 11 & $2(66.7)$ & $1(33.3)$ & 0 & \\
\hline 12 & 0 & $4(80.0)$ & $1(20)$ & \\
\hline 13 & 0 & $3(100)$ & 0 & \\
\hline & 0 & 0 & $1(100)$ & \\
\hline
\end{tabular}

done in Japan by Iseki K et al., 2003 which found cumulative incidences of ESRD per 1000 screens were, from the lowest to highest BMI quartile 2.48, $3.79,3.86$ and $5.81 .{ }^{21}$ The study showed that normal and underweight patients might be due to the patient on a normal diet under hemodialysis.

Mean hospital stay in this study was found to be more than six days. This was inconsistent with the result of Kshirsagar et.al, 2000, the study was done in North Carolina in which the length of hospital stay for admissions to the nephrology service was 6.3 days. ${ }^{22}$ The length of hospital stay in this study was found to higher which might be due to the presence of multiple comorbidities.

In the present study, the prevalence of hypertension is higher (31.25\%) and this result is slightly higher 
to the finding made by Dasari et al., 2014 in India in which $23.3 \%$ were found to be hypertensive patients. ${ }^{18}$ The higher prevalence of hypertension in a patient with CKD the reason behind this might be due to hypertension is the cause and complication of CKD and it is also difficult to control. ${ }^{23}$

In the present study, out of 135 antihypertensive drugs, most commonly prescribed 65 (48.14\%) were from diuretics. This finding is similar to 144 (46.1\%) to the study conducted in the North-Eastern part of Malaysia by Khan et al., 2016. ${ }^{24}$ The patient with moderate to the last stage of CKD has the problem of fluid overload, which is also associated with hypertension, congestive heart failure, left ventricular hypertrophy as well as edema, for this case diuretics are most commonly prescribed to control blood pressure and symptomatic relief. ${ }^{25}$

In this study, $19.75 \%$ of the drugs required dose adjustments were inappropriately prescribed and this result is similar to the study carried out at Tribhuvan University Teaching Hospital (TUTH), Kathmandu by Sah et al., 2015 which revealed $20 \%$ of inappropriate drugs for CKD patients. ${ }^{15}$ The medication dosing errors in the present study were much lower than the studies reported from Palestine, India and South Africa, whereby the percentages of unadjusted drugs were nearly $73.6 \%, 81.1 \%$, and $59.0 \%$ respectively. ${ }^{26-28}$ The medication error was found to be decreased in this study as compared to other underdeveloped countries which could be due to proper dosage by the skilled, trained nephrologist to the CKD patients.

In this study, it was found that dosing error was gradually increased as the staging of CKD was advancing e.g., with lesser $\mathrm{CrCl}$. Of the total 27 medications, the majority of drugs 13 (48.14\%) were inappropriately and only 4 (14.81\%) were adjusted appropriately in stage V CKD patients. These results are similar to another study conducted in Ethiopia by Getachew et al., $2015^{29}$ Out of the 10 number of prescription-only 2 (20\%) were found to be appropriately prescribed in the patient with stage $\mathrm{V} C K D$, which has a higher chance of dose inappropriateness due to multiple drugs prescribed to manage multiple disease condition.

The highest proportion of inappropriateness 8 $(50 \%)$ in age $>59$ was observed in the study which was followed by the age group 39-48 (18.75\%). The proportion of inappropriateness was higher in the older age group which might be due to the higher number of those age group patients who were admitted to the Nephrology ward. This result is supported by the result of Getachew et al., 2015, who showed that a greater proportion of inappropriate dose adjustment in prescription entries was observed in the elderly ( $\geq 60$ age group)..$^{29}$

The frequencies of inappropriately prescribed drugs for CKD patients were observed. In a total of 16 inappropriately adjusted drugs, antibiotic groups (Ciprofloxacin, levofloxacin, meropenem, nitrofurantoin) were frequently prescribed drugs (41.9\%). And among these antibiotics, nitrofurantoin (14\%) was the most commonly prescribed inappropriate drug because the dosage prescribed is not in conformity to the patient's $\mathrm{CrCl}$ as per the recommendation of The Renal Drug Handbook. ${ }^{30}$ These findings are in line with previous studies done by ${ }^{15,28}$. But this finding contradicts the study done by Getachew $\mathrm{H}$ et al., 2015, which found a high frequency of diuretics (spironolactone) as inappropriate drugs. ${ }^{29}$

\section{Limitation of The Study}

The data collection time was limited so it is also the limitation of the study. The sample size was less in number i.e. 80 which could not represent the whole scenario of CKD in Nepal was another limitation of this study.

\section{Recommendations}

Further research should be conducted to assess the impact of more variables such as the specific drug classes and the specific comorbidities on the medication dosing errors in chronic kidney disease patients. For the avoidance of harmful DDIs, interaction should be checked. ${ }^{31,32}$ Awareness creation programs should be conducted for healthcare professionals to minimize the risk associated with potentially harmful drug combinations. ${ }^{33}$ The multicenter study should be done for assessment of drug dose adjustment as well as drug-drug interaction in that site. Drug information via drug information center of the hospital can be provided to the CKD patients regarding $\mathrm{DDI}$ and $\mathrm{ADR} .{ }^{34}$ Further study should be conducted to find out the pharmacological management system of CKD in a hospital that either follows the standard guidelines of treatments or not in any tertiary care hospital. 


\section{CONCLUSION}

This study concluded that proper dose monitoring and adjustment was not done by the health care practitioners to the patient with CKD. The finding of this study specified the need for providing various guidelines and important information regarding dosage adjustment appropriateness to the health care provider to prevent dosage related toxicity in a patient with CKD. The present study indicated the need and role of health care provider for identifying and reducing dosage related medication error, which could be possible by providing sufficient updated clinical guidelines and health-related information to the prescriber. Therefore, a collaboration of physicians with a pharmacist or a clinical pharmacist is necessary for the early detection and prevention of dose-related medication error which will help to improve the therapeutic outcome and reduces the consequences associated with adverse events in the patients with CKD.

\author{
Abbreviations \\ GFR: Glomerular filtration rate; \\ CKD: Chronic kidney disease; \\ $\mathrm{CrCl}$ : Creatinine clearance; \\ SCr: Serum creatinine; \\ eGFR: Estimated glomerular filtration rate; \\ MDRD: Modification of diet in renal disease study: \\ ESRD: End-Stage Renal Disease; \\ HD: Hemodialysis; \\ IDWG: Interdialytic Weight Gain; \\ KDOQI: Kidney Disease Outcomes Quality \\ Initiatives; \\ LDL: Low-Density Lipoprotein; \\ LVH: Left Ventricular Hypertrophy; \\ NKF: National Kidney Foundation; \\ PD: Peritoneal Haemodialysis; \\ QOL: Quality Of Life; \\ WHO: World Health Organization
}

\section{REFERENCES}

1. Neuen BL, Chadban SJ, Demaio AR, Johnson DW Perkovic V. Chronic kidney disease and the global NCDs agenda. BMJ Global Health. 2017;2(2):e000380. https://doi.org/10.1136/bmjgh-2017-000380 [Pubmed]

2. Nwose EU, Obianke J, Richards RS, Bwitit PT, Igumbor EO. Prevalence and correlations of hepatorenal functions in diabetes and cardiovascular disease among stratified adults. Acta Biomed. 2019;90(1):97103. [Pubmed | Full Text | DOI]

3. Chapter 1: Definition and classification of CKD. Kidney Int Suppl (2011). 2013;3(1):19-62. https://doi. org/10.1038/kisup.2012.64 [Pubmed | Full Text ]

4. Levey AS, Becker C, Inker LA. Glomerular filtration rate and albuminuria for detection and staging of acute and chronic kidney disease in adults: a systematic review. JAMA. 2015;313(8):837-846. https://doi.org/10.1001/jama.2015.0602 [Pubmed | Full Text]

5. Ang HG, Pua YH, Subari NA. Mandatory continuing professional education in pharmacy: the Singapore experience. International journal of clinical pharmacy. Aug 2013;35(4):570-576. https://doi.org/10.1007/ s11096-013-9767-y [Pubmed | Full Text]

6. Verbeeck RK, Musuamba FT. Pharmacokinetics and dosage adjustment in patients with renal dysfunction. European Journal of Clinical Pharmacology. 2009/08/01 2009;65(8):757-773.https://doi.org/10.1007/ s00228-009-0678-8 [Pubmed | Full Text]

7. Swan SK, Bennett WM. Drug dosing guidelines in patients with renal failure. West $\mathrm{J}$ Med. 1992;156(6):633-638. [Pubmed | Full Text]

8. Talbert RL. Drug Dosing in Renal Insufficiency. The Journal of Clinical Pharmacology. 1994;34(2):99-110. https://doi.org/10.1002/j.1552-4604.1994.tb03973.x [Pubmed]

9. Hassan Y, Al-Ramahi RJ, Aziz NA, Ghazali R. Impact of a Renal Drug Dosing Service on Dose Adjustment in Hospitalized Patients with Chronic Kidney Disease. Annals of Pharmacotherapy. 2009;43(10):1598-1605. https://doi.org/10.1345/aph.1M187 [Pubmed]

10. Munar MY, Singh $H$. Drug dosing adjustments in patients with chronic kidney disease. American family physician. May 15 2007;75(10):1487-1496. [Pubmed]

11. Nobili A, Garattini S, Mannucci PM. Multiple diseases and polypharmacy in the elderly: challenges for the internist of the third millennium. J Comorb. 2011;1:28 44. https://doi.org/10.15256/joc.2011.1.4 [Pubmed]

12. Shrestha S, Shrestha S, Khanal S. Polypharmacy in elderly cancer patients: Challenges and the way clinical pharmacists can contribute in resourcelimited settings. Aging Med. 2019;2(1):42-49. https:// doi.org/10.1002/agm2.12051 [Full text | Pubmed]

13. Modig S, Lannering C, Östgren CJ, Mölstad S, Midlöv $P$. The assessment of renal function in relation to the use of drugs in elderly in nursing homes; a cohort study. BMC Geriatrics. 2011/01/11 2011;11(1):1. https://doi.org/10.1186/1471-2318-11-1 [Full Text]

14. Khatiwada S, Rajendra KC, Gautam S, Lamsal M, Baral N. Thyroid dysfunction and dyslipidemia in chronic kidney disease patients. BMC Endocr Disord. 2015;15:65-65.https://doi.org/10.1186/s12902-0150063-9 [Pubmed | Full text]

15. Sah SK, Wanakamanee U, Lerkiatbundit S, Regmi BM. Drug Dosage Adjustment of Patients with Impaired Renal Function at Hospital Discharge in a Teaching 
Hospital. Journal of Nepal Health Research Council. 2014-07-09 2014. [Full Text]

16. Cockcroft DW, Gault $\mathrm{MH}$. Prediction of creatinine clearance from serum creatinine. Nephron. 1976;16(1):31-41. https://doi. org/10.1159/000180580 [Full Text]

17. Jodoin K. The Renal Drug Handbook: The Ultimate Prescribing Guide for Renal Practitioners, 4th edition. European Journal of Hospital Pharmacy. 2016;23(4):248-248.https://doi.org/10.1136/ ejhpharm-2016-000883 [Full Text]

18. Dasari P, Venkateshwarlu K, Venisetty R. Management of comorbidities in chronic kidney disease: a prospective observational study. Int J Pharm Pharm Sci. 2014;6(2):363-367. [Full Text]

19. Kuznik A, Mardekian J, Tarasenko L. Evaluation of cardiovascular disease burden and therapeutic goal attainment in US adults with chronic kidney disease: an analysis of national health and nutritional examination survey data, 2001-2010. BMC Nephrology. 2013/06/27 2013;14(1):132. https://doi. org/10.1186/1471-2369-14-132 [Pubmed]

20. Mishra D, Koirala P. Status of chronic kidney disease patients registered in National Kidney Center, Banasthali, Kathmandu. Journal of Manmohan Memorial Institute of Health Sciences. 2015;1(4):1923.https://doi.org/10.3126/jmmihs.v1i4.11997 [Pubmed | Full Text]

21. Iseki K, Ikemiya $Y$, Kinjo K, Inoue $T$, Iseki C, Takishita $\mathrm{S}$. Body mass index and the risk of development of end-stage renal disease in a screened cohort. Kidney international. 2004;65(5):1870-1876.https:// doi.org/10.1111/j.1523-1755.2004.00582.x [Pubmed | Full Text |DOI]

22. Kshirsagar AV, Hogan SL, Mandelkehr L, Falk RJ. Length of stay and costs for hospitalized hemodialysis patients: nephrologists versus internists. Journal of the American Society of Nephrology : JASN. Aug 2000;11(8):1526-1533. [Pubmed | Full Text |DOI]

23. Lalor E. National Vascular Disease Prevention Alliance. Guidelines for the management of absolute cardiovascular disease risk. 2012. ISBN 978-09872830-1-6. https://stroke foundation. com. au/*/ media

24. Khan $Y H$, Sarriff A, Adnan AS, Khan AH, Mallhi TH. Chronic Kidney Disease, Fluid Overload and Diuretics: A Complicated Triangle. PLOS ONE. 2016;11(7):e0159335.https://doi.org/10.1371/ journal.pone.0159335 [Pubmed | Full Text | DOI]

25. London GM. Cardiovascular disease in chronic renal failure: pathophysiologic aspects. Seminars in dialysis. Mar-Apr 2003;16(2):85-94. https://doi.org/10.1046/ j.1525-139X.2003.16023.X

26. Sweileh $W M$, Janem $S A$, Sawalha $A F$, et al. Medication dosing errors in hospitalized patients with renal impairment: a study in Palestine. Pharmacoepidemiology and drug safety. Aug 2007;16(8):908-912.https://doi.org/10.1002/ pds.1412 [Pubmed | Full Text]

27. Decloedt $E$, Leisegang $R$, Blockman $M$, Cohen $\mathrm{K}$. Dosage adjustment in medical patients with renal impairment at Groote Schuur Hospital. South African Medical Journal (Suid-Afrikaanse tydskrif vir geneeskunde) 2010;100(5):304-306. https://doi. org/10.7196/SAMJ.3955 [Pubmed]

28. Prajapati A, Ganguly B. Appropriateness of drug dose and frequency in patients with renal dysfunction in a tertiary care hospital: A cross-sectional study. Journal of pharmacy \& bioallied sciences. 2013;5(2):136. https://doi.org/10.4103/0975-7406.111829

29. Getachew H, Tadesse $Y$, Shibeshi W. Drug dosage adjustment in hospitalized patients with renal impairment at Tikur Anbessa specialized hospital, Addis Ababa, Ethiopia. BMC Nephrology. 2015/10/07 2015;16(1):158._https://doi.org/10.1186/s12882015-0155-9 [Pubmed | Full Text]

30. Ashley C, Currie A. The renal drug handbook. Radcliffe Pub.; 2009. [Full Text]

31. Shrestha S, Danekhu K, Thapa S, Khanal S, Shankar PR. The Unmet Need for Pharmacists as Important Members of the Emergency Department Team in Resource-Limited Settings: A Case of Nepal. Journal of Pharmacy Technology. 2019;35(5):219-224. https:// doi.org/10.1177/8755122519850118 [Full text | DOI]

32. Shrestha S, Shrestha $S$, Palaian S. Can clinical pharmacists bridge a gap between medical oncologists and patients in resource-limited oncology settings? An experience in Nepal. Journal of Oncology Pharmacy Practice. 2019;25(3):765768.https://doi.org/10.1177/1078155218784734 [Pubmed | Full Text |DOI]

33. Sharma S, Khanal T, Shrestha S, Adhikari B. A celebration of World Pharmacist Day 2018 focusing to strengthen the pharmacy services at an oncology-based hospital in Nepal: Inspiration for others in developing countries. Research in Social and Administrative Pharmacy. 2019;15(1):117-118. https:// doi.org/10.1016/j.sapharm.2018.09.022 [Pubmed | Full Text | DOI]

34. Shrestha $S$, Khatiwada AP, Gyawali $S$, Shankar PR, Palaian S. Overview, Challenges and Future Prospects of Drug Information Services in Nepal: A Reflective Commentary. J Multidiscip Healthc. 2020;13:287-295. https://doi.org/10.2147/JMDH.S238262 [Pubmed Full Text | DOI] 